\title{
FEASIBILITY OF PRODUCING LIGHTWEIGHT CONCRETE USING INDIGENOUS MATERIALS WITHOUT AUTOCLAVING
}

\author{
M. Shamsuddoha ${ }^{(1)}$, M. M. Islam ${ }^{(2)}$ and M. A. Noor ${ }^{(3)}$ \\ 1. Lecturer, Department of Civil Engineering, Military Institute of Science and Technology \\ E-mail: doha.ce@mist.edu.bd \\ 2. Instructor Class-B, Department of Civil Engineering, Military Institute of Science and Technology \\ E-mail: monzur514@yahoo.com \\ 3. Professor, Department of Civil Engineering, Bangladesh University of Engineering and Technology \\ E-mail: mnoor@ce.buet.ac.bd
}

\begin{abstract}
This research shows the feasibility and sequential approach for producing lightweight concrete without autoclaving using indigenous ingredients and appropriate technology of Bangladesh. Ingredients were mixed chronologically using trial-and-error method to reduce unit weight. Specific volume principle was utilized to observe the effect of inclusion of cement, water, sand, lime and aluminium in the mixture to achieve the goal. Molds were used to accommodate volumetric expansion of mixture. Both $50 \mathrm{~mm}$ and $150 \mathrm{~mm}$ cubic specimens were prepared for tests. Density and compressive strength were determined for specimens. Absorption capacity and thermal conductivity were also determined to get the product performance. From the results, it was seen that density and compressive decreased with increased water-cement ratio. Volumetric expansion was high for higher volume surface ratio. Finally, lightweight concrete with density, compressive strength and thermal conductivity within range of $700-1000$ $\mathrm{kg} / \mathrm{m} 3,0.5-2.0 \mathrm{MPa}$ and $0.2-0.5 \mathrm{~W} / \mathrm{m}-\mathrm{k}$ respectively was produced.
\end{abstract}

KEY WORDS: Volumetric expansion, Lightweight concrete, Water-cement ratio, Mix design.

\subsection{INTRODUCTION}

Diverse use of lightweight concrete is well recognized all over the world. NRMCA (2003) suggested that the best suitable option to reduce dead load of a structure lie within the deduction of self-weight of concrete, which eventually reduces size of structural elements. Studies (Haug et al. 1996; Ahmed et al. 2004; Lijiu et al. 2005; Lo et al. 2006; Arisoy et al. 2008; Mouli et al. 2008) showed that lightweight concrete has wide opportunity not just as structural material but also other decorative elements due to performance and durability. Decoration elements such as timber, plastics are inadequate and their uses are concerned with adverse impacts on environment especially for a developing country like Bangladesh. Lightweight concrete is generally produced by two means (ACI 523.3R-93, ACI 213R-03). One is cellular concretes referred to lightweight concretes, which contain stable air or gas cells uniformly distributed in the mixture. Cellular concretes commonly include natural or manufactured sand aggregate. In other types, aggregates may be added; for example, manufactured lightweight aggregates such as expanded clay, shale, slate, sintered fly ash, perlite, and vermiculite as well as natural lightweight aggregates such as pumice, scoria, or tuff. Air cells can be intruded from outside through rigorous mixing or by chemically by mean of any reaction producing air bubbles. Due to unavailability of lightweight aggregate in Bangladesh, lightweight concrete was produced using chemically induced void in cement mortar matrix in this study. This research is aimed to observe the effect of volume-surface ratio and aluminium content on volumetric expansion of lightweight concrete.

\subsection{RESEARCH SIGNIFICANCE}

Lightweight concrete and its future prospects are well established but rigorous study has not been done yet on this field. This study is the pioneer feasibility approach for producing lightweight concrete in Bangladesh. This research enumerates possible indigenous materials those can be incorporated in producing lighter concrete for various decorative, infill and partition related constructions. This study will open new approach for improved large-scale super lightweight concrete production. Authors believe that as first of its kind in Bangladesh, the outcome provides 
ahead start for the next researchers interested in this field.

\subsection{EXPERIMENTAL Program}

\section{GENERAL APPROACH}

First phase of this research focused on the feasibility of reducing unit weight of concrete. "Trial and Error" method was utilized for the production of lightweight mortar from locally available materials such as Cement, Local sand, Lime, Aluminium Powder. Specific weight principle was utilized to see the contribution of ingredients in mixture. Although large amount of void was to be inserted in the matrix, specific weight basis analysis approach was applied for the research.

$\sum \frac{W_{i}}{S_{i}}=1000$

Here

$\mathrm{W}_{\mathrm{i}}=$ Weight of i materials in $\mathrm{kg}$

$\mathrm{S}_{\mathrm{i}}=$ Specific Gravity of i material

Next approach was to improvise production technique to optimize the goal. Effect of mold size on volumetric expansion of produced concrete was also observed.

\section{PROPORTIONS}

Five mixture bands were made to compare the effect of inclusion of ingredients to produce lightweight concrete. First band; B-1 was prepared to observe the void intrusion by aluminium in the cement matrix. Cement content and water content were 1071 and $643 \mathrm{~kg} / \mathrm{m} 3$ respectively along with varied cement-aluminium ratio by weight. Next band of mixture; B-2 was selected to visualize initial condition of mortar mixture without compaction and expansive agent for varying water-cement ratio from 0.40 to 0.85 . Constant sand-cement ratio 1.5 was used in this research as this ratio is widely used in normal weight concrete. Mix proportion B-3 and B-4 were implemented to observe the effect of aluminium and lime respectively. To accommodate volumetric expansion, $150 \mathrm{~mm}$ cube mold was used in mix band; B-5 and B-6 having cement-aluminium ratio 100 and 50 respectively. B-4 and B-6 were containing identical mix proportion with different mold capacity (50 $\mathrm{mm}$ and $150 \mathrm{~mm}$ cube respectively). These are reported in Table 1. Water-cement ratio for the mix bands was not identical due to trial and error approach. On affirmation test results of a band another band was formed and tested. Absorption capacity and thermal conductivity were also determined to obtain product properties.

\section{TEST SPECIMEN}

Mixtures were prepared in steel bowls mixing the ingredients. Specimens were cast in $50 \mathrm{~mm}$ steel cube $\quad\left(\right.$ Volume $/$ Surface $\left.=\frac{50 \times 50 \times 50}{4 \times 50 \times 50}=12.5\right)$. No vibration was used on low viscous mixture to avoid segregation and uniform distribution of bubbles. Side and bottom joints of moulds were sealed with grease to resist water leakage. Samples were removed from mould after 24 hours and cut to $50 \mathrm{~mm}$ cubes. Figure 1 referred. Samples were allowed to cure for 28 days. Density and compressive strength were determined for samples. Same procedure was applied for $150 \quad \mathrm{~mm}$ cube ( Volume $/$ Surface $=\frac{150 \times 150 \times 150}{4 \times 150 \times 150}=37.5$ ) during second phase of the research, thereby effect of volumesurface ratio on volumetric expansion was observed. Absorption capacity and thermal conductivity of selected samples was determined to get property trend. Samples were cut to size required for thermal conductivity test by apparatus of Lee's method (Young 2006). 


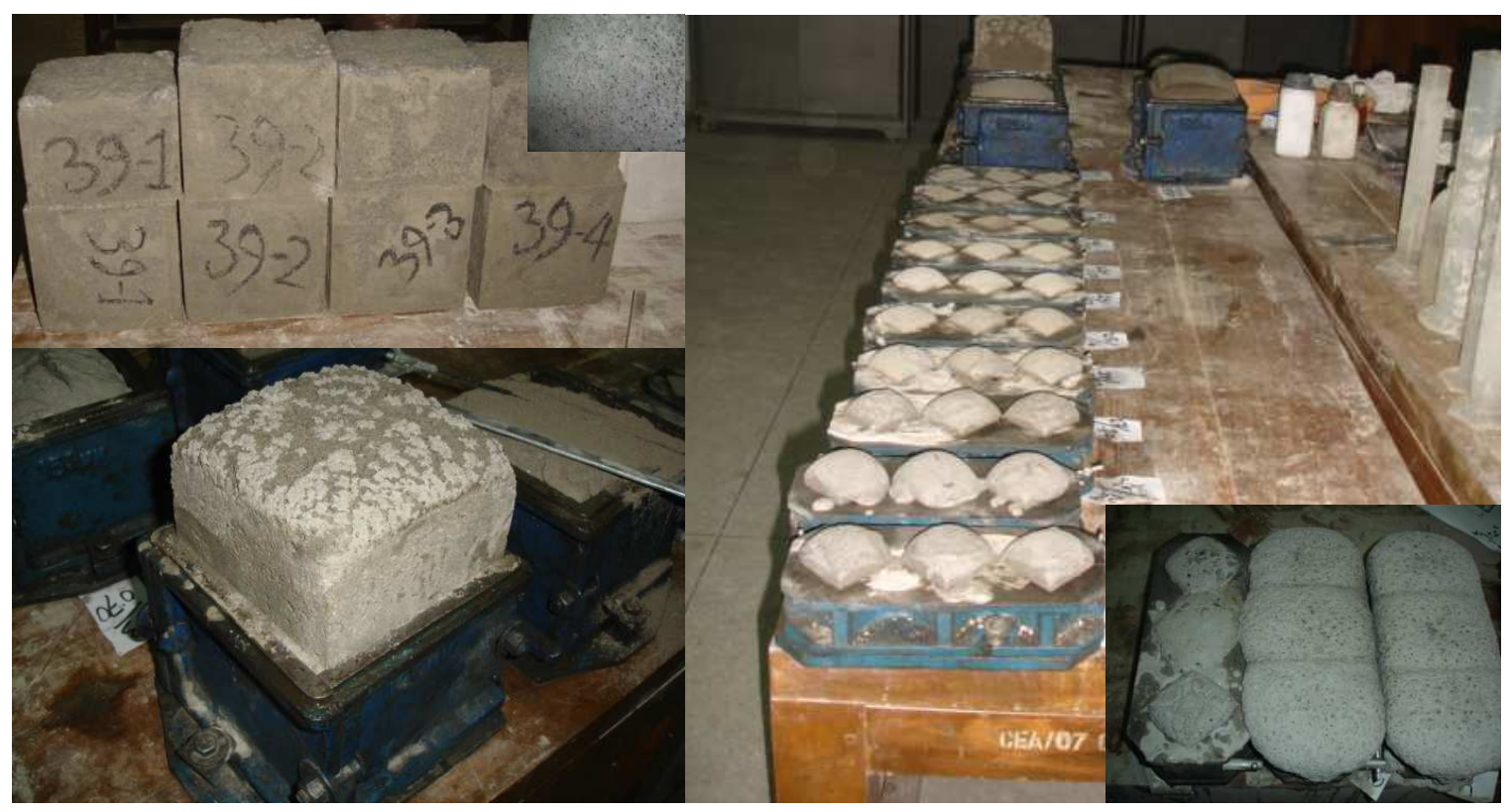

Figure 1: Volumetric expansion in cube sample and voids distribution in mortar matrix

\subsection{MATERIALS}

As prime binder in this investigation commonly available cement CEM II (BDS 197-1); Portland Composite Cement (PCC) with specific gravity 3.0 was used. Cement was tested for strength conforming ASTM C 109 and fineness conforming ASTM C 204. Average compressive strength of PCC for 3-days, 7-days and 28-days were 17, 21 and $30 \mathrm{MPa}$, respectively. Test by Blaine's apparatus suggests PCC having fineness $330 \mathrm{~m}^{2} / \mathrm{kg}$. Most commonly available sand of Bangladesh is Savar sand. Basic physical properties were determined for Savar sand used for this research. Unit weight was measured as per ASTM C 29, specific gravity and absorption capacity were determined conforming ASTM C 128 and sieve analysis was conducted conforming ASTM C 136. Specific gravity (OD), Specific gravity (SSD), Apparent specific gravity, Absorption capacity, Unit weight (loose), Unit weight (Compact) and Fineness modulus were found $2.14,2.33,2.63,8.67 \%, 1346 \mathrm{~kg} / \mathrm{m}^{3}, 1484$ $\mathrm{kg} / \mathrm{m}^{3}$ and 1.02 respectively. For this research, lime is used as an expansive agent for its violent volumetric slaking in presence of water (Aziz 1995). Unslaked local lime was finely ground to get fine powder. Specific gravity of lime was 2.40. To ensure uniform fineness, ground lime was screened through \#200 ASTM sieve.
Aluminium powder was the prime void intruder in this research. Pure aluminium reacts with water as Equation 2 to produce Hydrogen gas (Haque and Alam 2007, Rosa 2009).

$$
2 \mathrm{Al}+6 \mathrm{H}_{2} \mathrm{O}=2 \mathrm{Al}(\mathrm{OH})_{3}+3 \mathrm{H}_{2}(\uparrow)
$$

Aluminium powder containing $99.9 \%$ assay was used to get desired void intrusion.

\subsection{EXPERIMENTAL RESULTS}

Materials identified as potential ingredients of aircrete were not enough to produce required void inside concrete matrix. Thus a bubble intruder; aluminium powder was introduced. Figure 2 shows effect of aluminium content on strength and density. To get a comparison, cement content and water content were kept fixed as $1071 \mathrm{~kg} / \mathrm{m}^{3}$ and $643 \mathrm{~kg} / \mathrm{m}^{3}$, respectively. Results show that density decreases with increased aluminium content but strength declined. However, this study was done in aim of identifying aluminium content to get desired void intrusion. The aluminium content was selected as $1 \mathrm{gm}$ of aluminium for 50 gm of cement for B-2, B-3, B-4 and B-6. This content was conservative but consideration was kept in mind that sand and other fillers; if required would have to be inserted yet. Cement alone is a 
very expensive material and should be associated with other filler like sand or coarse aggregate. As filler, Savar sand was used in this research. Table 1 represents mix proportions and corresponding test results. Compressive strength and density of tested specimens are shown in Figure 3 and Figure 4 respectively. Variation of strength and density are plotted for mix bands B-2, B-3, B-4, B-5 and B-6 with respect to water-cement ratio.

\begin{tabular}{|c|c|c|c|c|c|c|c|}
\hline Mix Design & $\mathrm{S} / \mathrm{C}$ & $\mathrm{C} / \mathrm{L}$ & $\mathrm{W} / \mathrm{C}$ & $\mathrm{C} / \mathrm{A}$ & $\begin{array}{l}\text { Compressive } \\
\text { Strength }^{\mathrm{a}}\end{array}$ & Density $^{b}$ & Mold Size \\
\hline \multirow{9}{*}{ B-1 } & \multirow{9}{*}{-} & \multirow{9}{*}{-} & \multirow{9}{*}{0.60} & 500 & 4.98 & 1066 & \multirow{9}{*}{$50 \mathrm{~mm}$} \\
\hline & & & & 333 & 4.65 & 1065 & \\
\hline & & & & 250 & 4.36 & 1041 & \\
\hline & & & & 200 & 3.97 & 1035 & \\
\hline & & & & 125 & 2.84 & 953 & \\
\hline & & & & 100 & 2.07 & 917 & \\
\hline & & & & 67 & 1.19 & 836 & \\
\hline & & & & 50 & 0.65 & 685 & \\
\hline & & & & 32 & 0.37 & 606 & \\
\hline \multirow{10}{*}{ B-2 } & \multirow{10}{*}{1.5} & \multirow{10}{*}{-} & 0.40 & \multirow{10}{*}{ - } & 8.26 & 1864 & \multirow{10}{*}{$50 \mathrm{~mm}$} \\
\hline & & & 0.45 & & 15.44 & 2192 & \\
\hline & & & 0.50 & & 15.85 & 2136 & \\
\hline & & & 0.55 & & 15.06 & 2216 & \\
\hline & & & 0.60 & & 12.14 & 2101 & \\
\hline & & & 0.65 & & 11.98 & 2091 & \\
\hline & & & 0.70 & & 8.87 & 2192 & \\
\hline & & & 0.75 & & 7.96 & 2160 & \\
\hline & & & 0.80 & & 6.45 & 2064 & \\
\hline & & & 0.85 & & 4.93 & 2013 & \\
\hline \multirow{10}{*}{ B-3 } & \multirow{10}{*}{1.5} & \multirow{10}{*}{ - } & 0.40 & \multirow{10}{*}{50} & 5.52 & 1851 & \multirow{10}{*}{$50 \mathrm{~mm}$} \\
\hline & & & 0.45 & & 7.99 & 1744 & \\
\hline & & & 0.50 & & 13.67 & 1829 & \\
\hline & & & 0.55 & & 10.68 & 1747 & \\
\hline & & & 0.60 & & 6.32 & 1701 & \\
\hline & & & 0.65 & & 6.01 & 1627 & \\
\hline & & & 0.70 & & 6.65 & 1653 & \\
\hline & & & 0.75 & & 5.00 & 1635 & \\
\hline & & & 0.80 & & 4.39 & 1488 & \\
\hline & & & 0.85 & & 4.10 & 1635 & \\
\hline
\end{tabular}

Table-1: Detail Proportion of Concrete Mixes and Properties of Lightweight Concrete

C: Cement Content; S: Sand Content; L: Lime Content; A: Aluminium, W: Water Content All Content ratios are by weight

${ }^{\mathrm{a}} \mathrm{kg} / \mathrm{m}^{3}$

${ }^{\mathrm{b}} \mathrm{MPa}$ 
Table-1: (Continued...)

\begin{tabular}{|c|c|c|c|c|c|c|c|}
\hline Mix Design & $\mathrm{S} / \mathrm{C}$ & $\mathrm{C} / \mathrm{L}$ & $\mathrm{W} / \mathrm{C}$ & $\mathrm{C} / \mathrm{A}$ & Density $^{a}$ & $\begin{array}{l}\text { Compressive } \\
\text { Strength }^{\mathrm{b}}\end{array}$ & Mold Size \\
\hline \multirow{10}{*}{ B-4 } & \multirow{10}{*}{1.5} & \multirow{10}{*}{4.0} & 0.40 & \multirow{10}{*}{50} & 2.41 & 1659 & \multirow{10}{*}{$50 \mathrm{~mm}$} \\
\hline & & & 0.45 & & 6.21 & 1885 & \\
\hline & & & 0.50 & & 9.45 & 1939 & \\
\hline & & & 0.55 & & 8.51 & 1816 & \\
\hline & & & 0.60 & & 8.66 & 1840 & \\
\hline & & & 0.65 & & 6.50 & 1725 & \\
\hline & & & 0.70 & & 4.46 & 1605 & \\
\hline & & & 0.75 & & 3.49 & 1549 & \\
\hline & & & 0.80 & & 2.62 & 1363 & \\
\hline & & & 0.85 & & 2.07 & 1317 & \\
\hline \multirow{13}{*}{ B-5 } & \multirow{13}{*}{1.5} & \multirow{13}{*}{4.0} & 0.60 & \multirow{13}{*}{100} & 4.95 & 1546 & \multirow{13}{*}{$150 \mathrm{~mm}$} \\
\hline & & & 0.65 & & 4.62 & 1574 & \\
\hline & & & 0.70 & & 3.91 & 1405 & \\
\hline & & & 0.75 & & 3.02 & 1383 & \\
\hline & & & 0.80 & & 3.38 & 1355 & \\
\hline & & & 0.85 & & 2.79 & 1263 & \\
\hline & & & 0.90 & & 2.23 & 1145 & \\
\hline & & & 0.95 & & 2.78 & 1215 & \\
\hline & & & 1.00 & & 2.32 & 1189 & \\
\hline & & & 1.05 & & 2.02 & 1084 & \\
\hline & & & 1.10 & & 1.32 & 1102 & \\
\hline & & & 1.15 & & 0.54 & 1093 & \\
\hline & & & 1.20 & & 0.34 & 1070 & \\
\hline \multirow{10}{*}{ B-6 } & \multirow{10}{*}{1.5} & \multirow{10}{*}{4.0} & 0.75 & \multirow{10}{*}{50} & 0.99 & 1071 & \multirow{10}{*}{$150 \mathrm{~mm}$} \\
\hline & & & 0.80 & & 1.05 & 1010 & \\
\hline & & & 0.85 & & 0.97 & 1010 & \\
\hline & & & 0.90 & & 0.91 & 971 & \\
\hline & & & 0.95 & & 0.68 & 935 & \\
\hline & & & 1.00 & & 0.61 & 884 & \\
\hline & & & 1.05 & & 0.59 & 868 & \\
\hline & & & 1.10 & & 0.68 & 857 & \\
\hline & & & 1.15 & & 0.42 & 842 & \\
\hline & & & 1.20 & & 0.39 & 810 & \\
\hline
\end{tabular}

C: Cement Content; S: Sand Content; L: Lime Content; A: Aluminium, W: Water Content All Content ratios are by weight ${ }^{\mathrm{a}} \mathrm{kg} / \mathrm{m}^{3}$

${ }^{\mathrm{b}} \mathrm{MPa}$

Significant change in density was observed when mold was changed from $50 \mathrm{~mm}$ to $150 \mathrm{~mm}$. B-6 producing low density $\left(<1000 \mathrm{~kg} / \mathrm{m}^{3}\right)$ but low strength $(<1 \mathrm{MPa})$ concrete. Absorption capacity and thermal conductivity (Lee's Method) of aircrete $\left(<1000 \mathrm{~kg} / \mathrm{m}^{3}\right)$ were determined and found within range of $20-25 \%$ and $0.2-0.5 \mathrm{~W} / \mathrm{m}-\mathrm{k}$ respectively. 


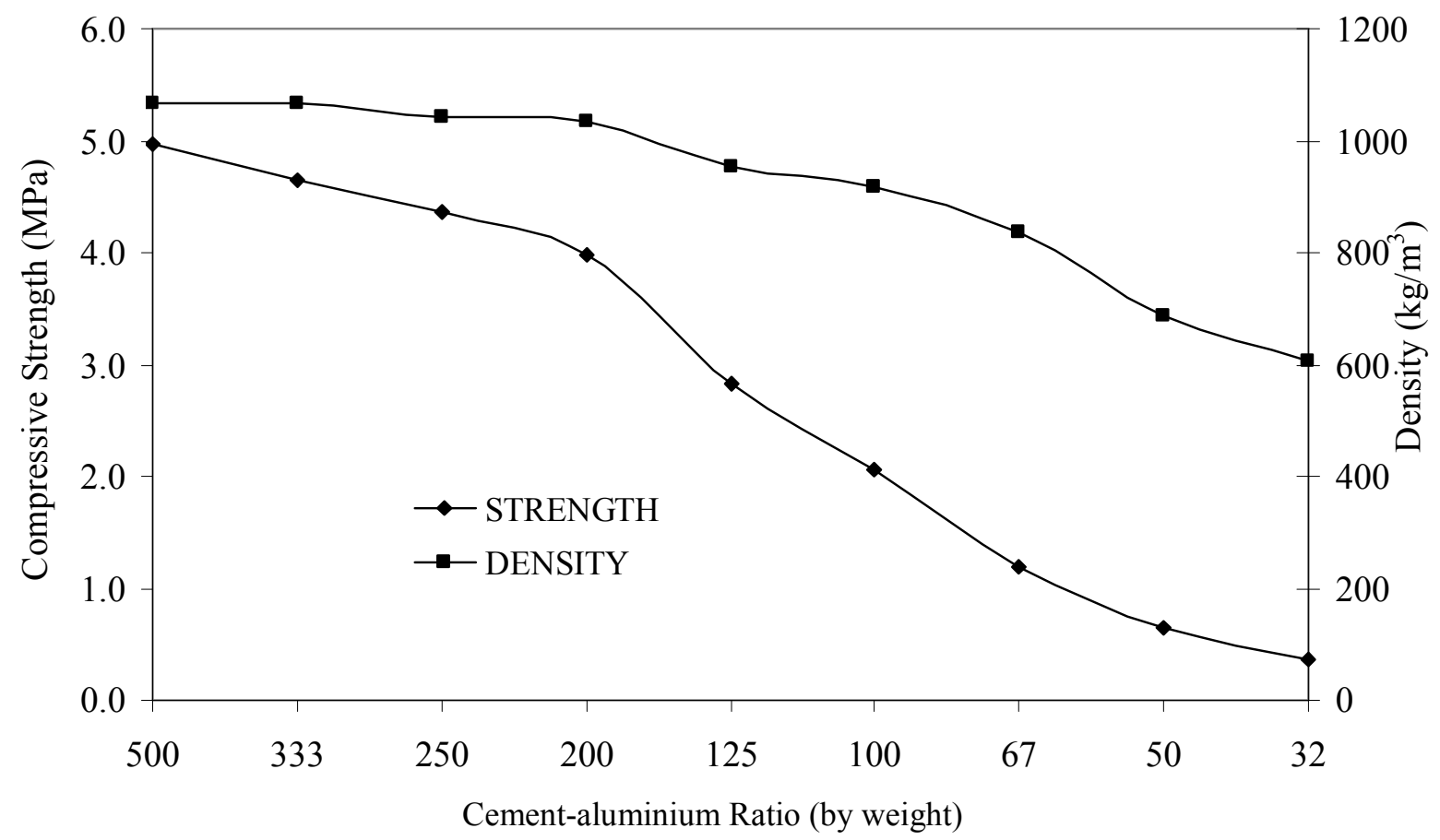

Figure 2: Effect of Aluminium content on density and compressive strength of hardened cement $\left(1071 \mathrm{~kg} / \mathrm{m}^{3}\right)$ with water $\left(643 \mathrm{~kg} / \mathrm{m}^{3}\right)$

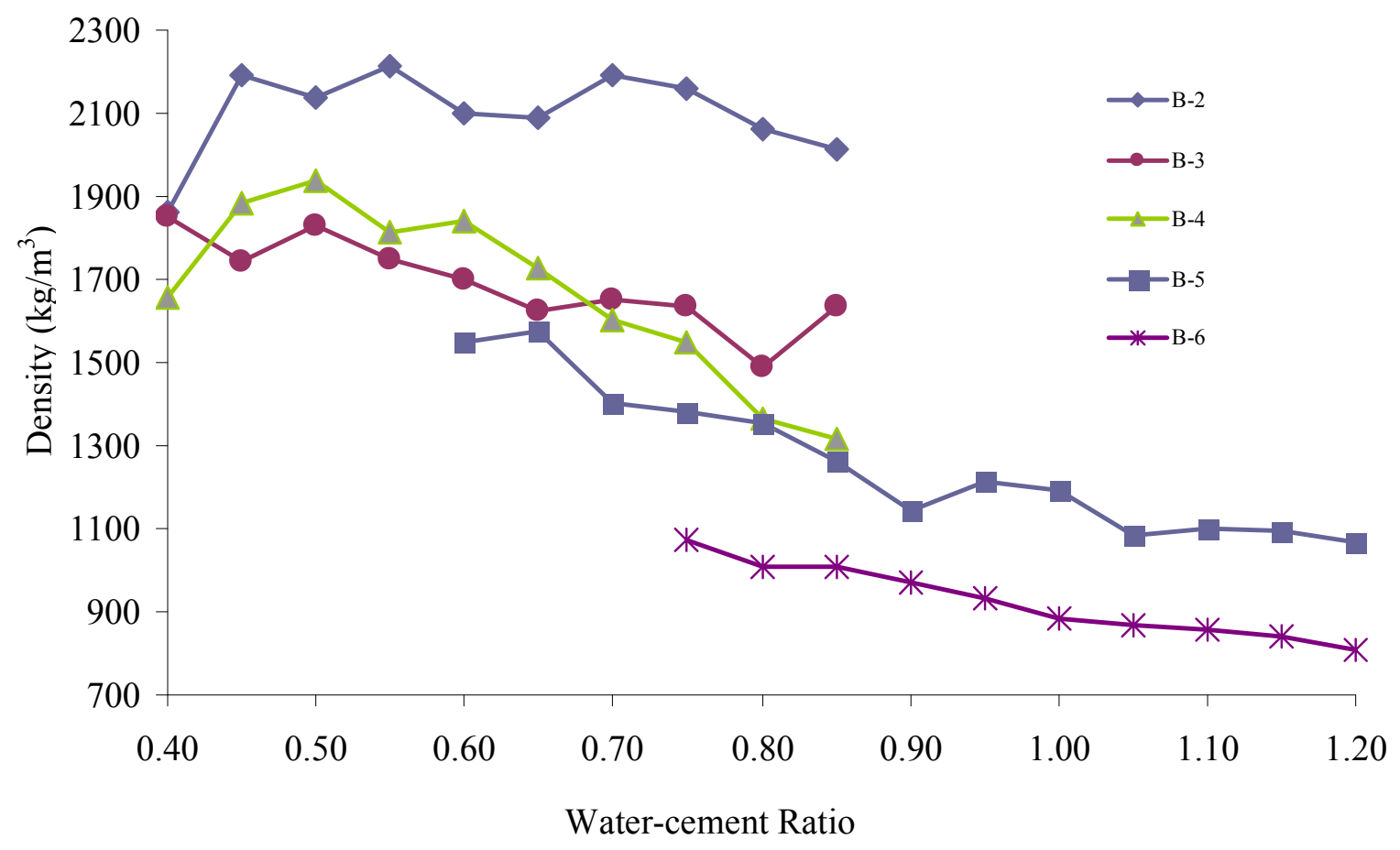

Figure 3: Relationship between density and water cement ratio 


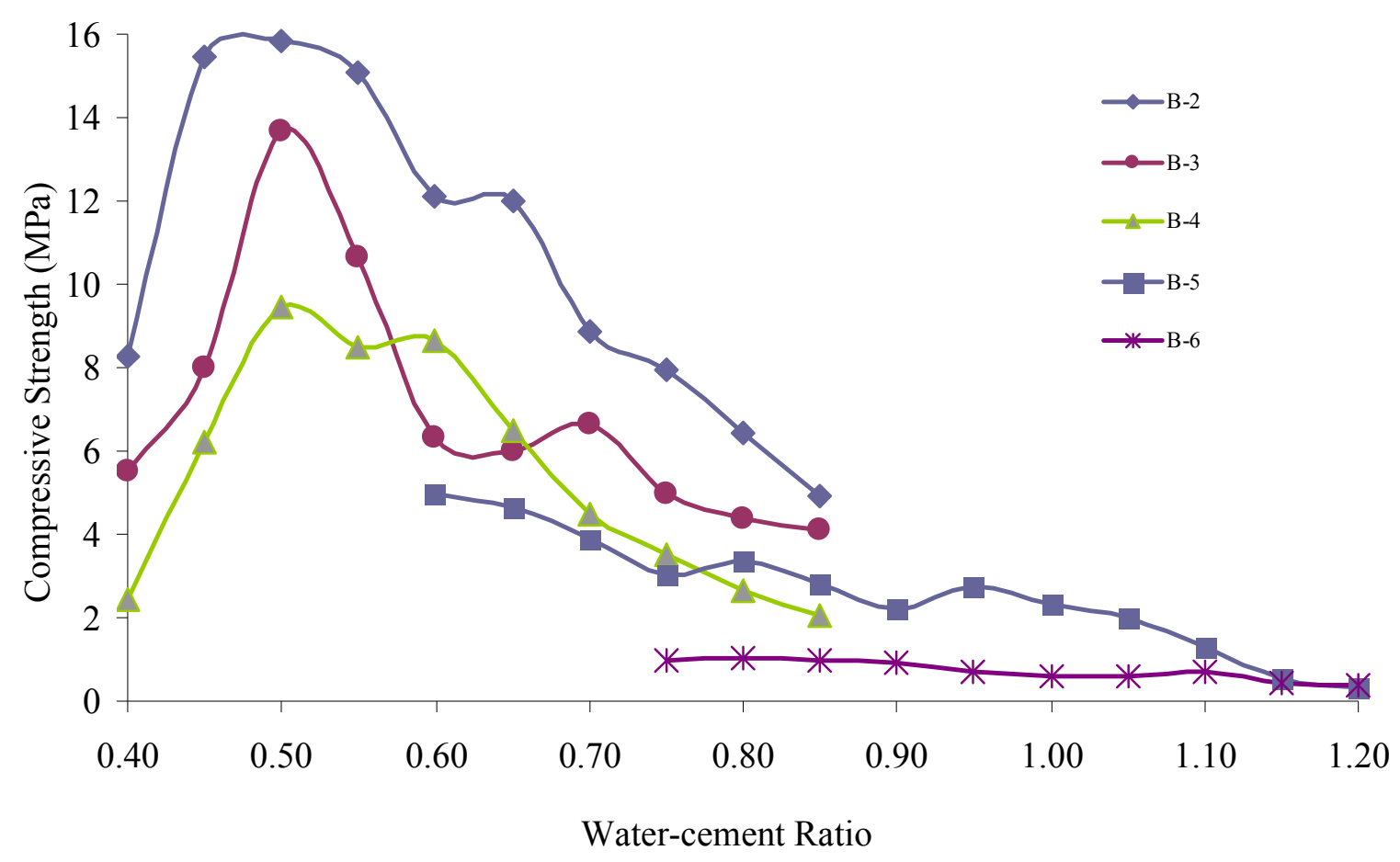

Figure 4: Relationship between compressive strength and water cement ratio

\subsection{Discussions}

Aluminium powder was successfully able to introduce void in the mortar matrix as seen from Figure 2. With the progress of mix bands from B2 to B-6, density can be reduced up to as low as 1000 to $700 \mathrm{~kg} / \mathrm{m}^{3}$ and subsequently strength reduced up to 2.0 to $0.40 \mathrm{MPa}$. Increased aluminium content would reduce the density but subsequently reduce the strength of hardened mortar. Mix proportion B-2 showed almost plateau density but sharply decreasing strength starting from water-cement ratio 0.50. No significant behavior could be characterized below water-cement ratio 0.50 . This anomalous behavior may be due to zero compaction provided on the mixture thereby leaving large voids. However, water content played vital role in void stabilization in the matrix. Decreasing trend shown by mix proportions B-2, B-3 and B-4 suggested the water cement ratio to higher values up to 1.20 . Moreover, density below $1000 \mathrm{~kg} / \mathrm{m}^{3}$ was found for water-cement ratio more than 0.90 in mix B-6. Neglecting anomalous fluctuation of density and compressive strength below watercement ratio 0.50 of $\mathrm{B}-4, \mathrm{~B}-5$ and $\mathrm{B}-6$, exponential trend can be imposed on the relation as shown in Figure 5. Statistical comparison with extrapolation was done to idealize the relation between density, strength and water-cement ratio. Containing identical mix proportion, B-4 and B-6 are showing varied volumetric expansion due to increase in volume-surface ratio at a ratio 1:3. Increased cement-aluminium ratio; 100 to 50 led to increased volumetric expansion thereby reduced density as seen from the comparison of B-5 and B-6. However, density trend was more pronounced to characterize than that of strength. Section of cube samples suggested formation of voids 2 to $15 \mathrm{~mm}$ in size forming honeycomb structure. 

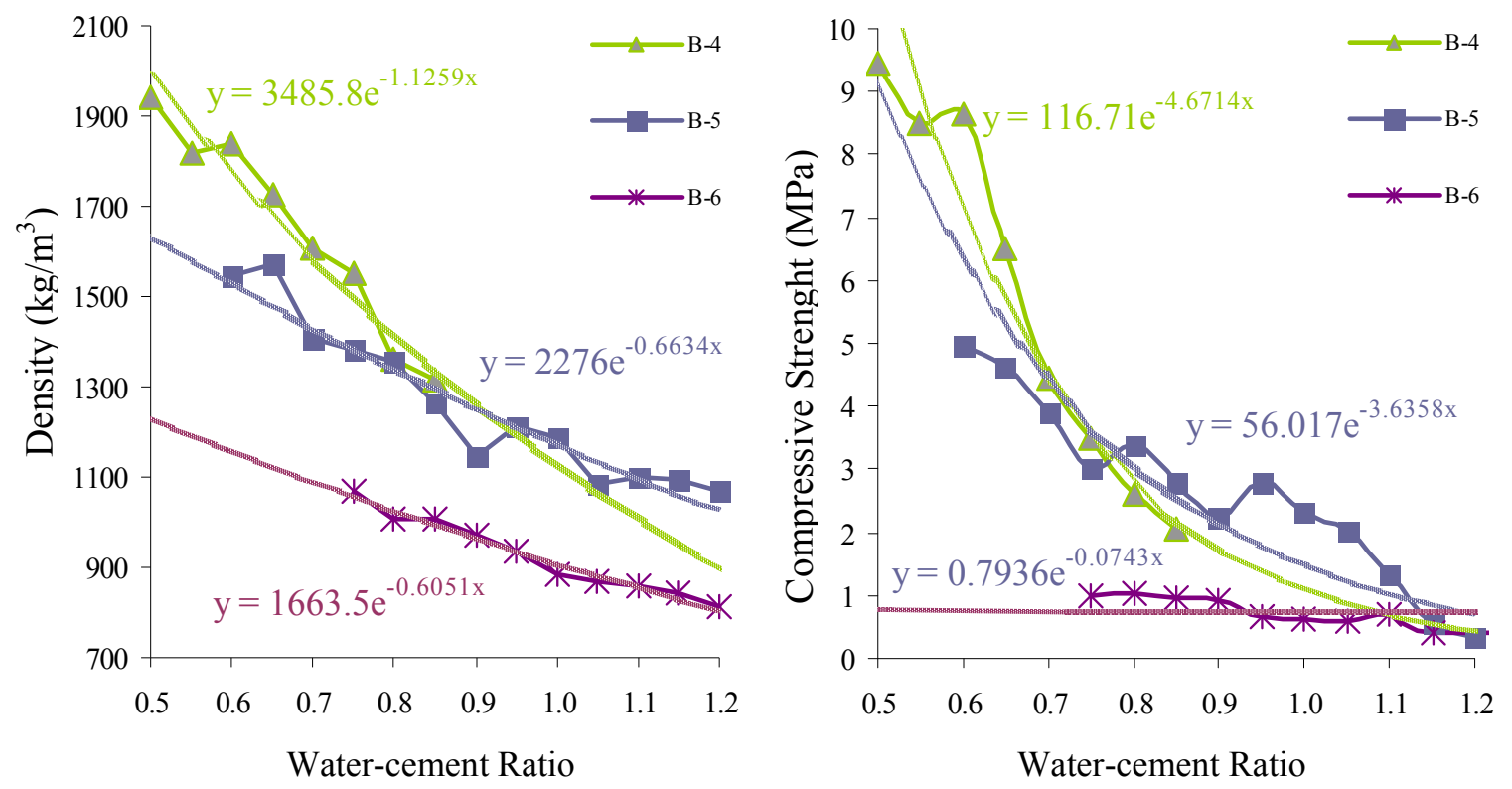

Figure 5: Comparison of Density and Compressive Strength due to increment of Volume-surface Ratio and Aluminium Content

\subsection{FURTHER RESEARCH}

Due to time and resource constrains, more detail study was not possible. Mix proportions with variable aggregate-cement ratio and cement-lime ratio should be applied to observe wide range of performance. Effort should be made to produce lightweight concrete using improved curing to achieve higher strength. Vapor curing at the initial stage of volumetric expansion may improve product quality. More material options (ordinary portland cement, plasticizer, viscous admixture) may be introduced to enhance performance.

\subsection{CONCLUSIONS}

The following conclusions can be drawn on the results of this investigation:

After a series of trials comprising indigenous options, density of concrete was able to be reduced within range of $700-1000 \mathrm{~kg} / \mathrm{m}^{3}$. However, strength was very low $(0.5-2.0 \mathrm{MPa})$. Absorption capacity and thermal conductivity was within the range of $0.2-0.5 \mathrm{~W} / \mathrm{m}-\mathrm{k}$.

As per RILEM classification, lightweight concrete produced in this research can be grouped under class-III and Insulating type lightweight concrete (RILEM 1978).
The reasons behind lower strength are high watercement ratio, less cementation index and foamy honeycomb structure of hardened mortar.

Within the domain of water-cement ratio 0.50 to 1.20 , density and compressive strength trend suggest 10 to $40 \%$ reduction in density and 50 to $90 \%$ reduction in strength due to increment of volume-surface ratio from 1:3 by introducing 150 $\mathrm{mm}$ cube in place of $50 \mathrm{~mm}$ cube whereas 20 to $25 \%$ density reduction and 0 to $80 \%$ strength reduction was observed by increasing cementlime ratio from 100 to 50 .

Finally, it can be concluded that lightweight concrete is feasible using indigenous materials and appropriate technology in Bangladesh.

\section{REFERENCES}

[1] ACI (1993), "Guide for Cellular Concretes above 50 pcf and for Aggregate Concrete above 50 pcf with Compression Strength Less than 2500 psi," ACI Task Committee 523, Michigan: American Concrete Institute, ACI 523.3R-93.

[2] ACI (2003), "Guide for Structural LightweightAggregate Concrete”, ACI Task Committee 213, Michigan: American Concrete Institute, ACI 213R-03. 
[3] Ahmed A., Fried A. N., Limbachiya M. C. and Roberts J. J. (2004), “Advantages and Implications of High Performance Low Density Aircrete Product for the UK Construction Industry", $13^{\text {th }}$ International Brick and Block Masonry Conference. Amsterdam, July 4-7, 2004.

[4] Arisoy B. and Wu H.-C. (2008), "Material Characteristics of High Performance Lightweight Concrete Reinforced with PVA." Construction and Building Materials [online], 22 (2008), 635-645, Available from: <www.sciencedirect.com $>$ [Accessed 20 Oct 2009].

[5] Aziz, M. A. (1995). "Engineering Materials." Dhaka: Z \& Z Publications.

[6] Haque, N., and Alam, Z. (2007). "Higer Secondary Chemistry." 5th ed, Dhaka: Ideal Publications.

[7] Haug, A. K. and Fjeld S., (1996). "A Floating Concrete Platform Hull made of Lightweight aggregate." Engineering Structures [online], 18 (11). Available from: <www.sciencedirect.com $>$ [Accessed 16 Aug 2008].

[8] National Ready Mix Concrete Association, (2003). "Structural Lightweight Concrete." Concrete in Practice [online], CIP-36. Available from: $<$ http://www.nrmca.org/aboutconcrete/cips/36p.pdf $>$ [Accessed on 24 June 2008].

[9] Lijiu W., Shuzhong Z. and Guofan Z. (2005), "Investigation of the Mix Design of Lightweight Aggregate Concrete." Cement and Concrete Research [online]. 35 (2005), 931-935, Available from: $<$ www.sciencedirect.com> [Accessed 16 Aug 2008].

[10] Lo T. Y., Cui H. Z., Abid N. and Li Z. G. (2006), "The Effects of Air Contents on Permeability of Lightweight Concrete." Cement and Concrete Research [online], 36 (2006), 1874-1878, Available from: <www.sciencedirect.com> [Accessed 16 Aug 2008].

[11] Mouli M. and Khelafi H. (2008), "Performance Characteristics of Lightweight Aggregate Concrete
Containing Natural Pozzolan." Building and Environment [online], 43 (2008), 31-36, Available from: <www.sciencedirect.com> [Accessed $20 \mathrm{Nov}$ 2009].

[12] Newman J. B. (1993), "Properties of Structural Lightweight Aggregate Concrete," In: Structural Lightweight Aggregate Concrete, Clarke, J. L. Ed. Glasgow: Chapman \& Hall, 19-41.

[13] RILEM (1978). "Functional Classification of Lightweight Concretes." Recommendation LC2, 1st ed., France.

[14] Rosa, A. V. D. (2009). "Fundamentals of Renewable Energy Processes." 2nd ed., Burlington: Academic Press.

[15] Van Geem M. G. (1990). "Heat Transfer Characteristics of a Recently Developed Structural Lightweight Concrete," In: Insulating Materials, Testing and Applications Testing and Applications, Philadelphia: American Society for Testing and Materials, 437-463.

[16] Young P. L. (2006). “A Level Physics.” Vol-1, Singapore: Penpac Education Private Limited.. 